\title{
An Experimental-Theoretical Study on Static Batch Sublimation with Laminar Flow and Constant Wall Temperature
}

\author{
Mohammad Outokesh ${ }^{1}$, Amirreza Mottafegh ${ }^{1}$, A. Nouri-Borujerdi ${ }^{1}$, Saeed Dolati ${ }^{1}$, Sayed \\ Isar Tabatabai Ghomsheh ${ }^{1}$, Seyed Javad Ahmadi², and Ali Faham Mofrad ${ }^{1}$ \\ ${ }^{1}$ Sharif University of Technology \\ ${ }^{2}$ Affiliation not available
}

April 28, 2021

\begin{abstract}
The major features of a static batch sublimation process over a hot plate with constant temperature were investigated in an experimental-theoretical study. An experimental apparatus with a real-time display was built to sublimate dry ice blocks of different sizes, in either circular or rectangular geometries. When temperature of the hotplate was changed from -30 to $200 \mathrm{oC}$, heat transfer coefficient "hsub" decreased from 126 to $70 \mathrm{~W} / \mathrm{m} 2 \mathrm{~K}$, while thermal flux increased, linearly. Weight and area of the block had a positive/negative effects on heat transfer, respectively. In theoretical part, two "linear- gradient" and "cubic" models were developed by a combined mass-momentum-energy balance. The latter used Von Karman temperature profile, and in cases of circular and rectangular geometries could estimate "hsub" with 17.8 and $13.5 \%$ average error. Linear-gradient was analytic, with similar accuracy in the circular case. The developed model are especially useful for design of sublimation equipment in purificationofthechemicals
\end{abstract}

\section{Hosted file}

Main Manuscript.pdf available at https://authorea.com/users/410756/articles/520007-anexperimental-theoretical-study-on-static-batch-sublimation-with-laminar-flow-andconstant-wall-temperature

\section{Hosted file}

Figures.pdf available at https://authorea.com/users/410756/articles/520007-an-experimentaltheoretical-study-on-static-batch-sublimation-with-laminar-flow-and-constant-walltemperature

\section{Hosted file}

Table.pdf available at https://authorea.com/users/410756/articles/520007-an-experimentaltheoretical-study-on-static-batch-sublimation-with-laminar-flow-and-constant-walltemperature 